\title{
ARBITRATION UNDER THE FEDERAL STATUTE
}

\section{WHARTON POOR}

Within the past few years an alteration has been made in our system of legal remedies for which very great claims have been made by its advocates. It is so well known as to make the statement almost superfluous, that at common law an agreement to arbitrate is not specifically enforceable and may be disregarded by either party. While it is true that such an agreement was not regarded as positively illegal and damages could be had for its breach, yet such damages were vague and indefinite and in at least one instance recovery was denied on that ground. ${ }^{2}$

The reasons which led the courts to refuse to enforce arbitration agreements are not now germane. While the judges may have felt that justice would be done in all causes coming before them and therefore arbitrations were unnecessary and perhaps mischievous, the fact must not be overlooked that the common law rule in substance voided all arbitration agreements, no matter how deliberately entered into. In other words, the parties were encouraged to repudiate their engagements.

This defect in the law was remedied in England by an Act passed in 1854,2 now superseded by the Arbitration Act of 1889. The British system of enforcing arbitration agreements did not, however, commend itself to our legislators, for it was not until 1920 that a statute making an agreement to arbitrate specifically enforceable was passed in New York. On February 12, 1925, the Federal Act, patterned after the New York Act, was passed.5

Our federal government has, of course, only a limited jurisdiction in the premises. The Constitution, however, entrusts to it the regulation of interstate commerce and bestows upon the federal courts admiralty jurisdiction. The Federal Act is limited to these matters.

The scope of the statute is defined as follows: ${ }^{5}$

'That 'maritime transactions,' as herein defined, means charter parties, bills of lading of water carriers, agreements relating to

${ }_{1}^{1}$ Munson v. Straits of Dover S. S. Co., 99 Fed. 787 (S. D. N. Y. 1900).

2 (1854) 17 \& 18 Vict., c. 125 (Common Law Proc. Act, \$11).

3 (1889) 52 \& 53 Vict., c. 49.

${ }^{4}$ N. Y. Laws 1920 , c. 275.

${ }^{5}$ Act of Feb. 12, 1925, 43 Stat. 883. This statute did not talise effect until Jan. 1, 1926, and has no application to contracts entered into prior to that date.

${ }^{6}$ Section 1. 
wharfage, supplies furnished vessels or repairs to vessels, collisions, or any other matters in foreign commerce which, if the subject of controversy, would be embraced within admiralty jurisdiction; 'commerce,' as herein defined, means commerce among the several States or with foreign nations, or in any Territory of the United States or in the District of Columbia, or between any such Territory and another, or between any such Territory and any State or foreign nation, or between the District of Columbia and any State or Territory or foreign nation, but nothing herein contained shall apply to contracts of employment of seamen, railroad employees, or any other class of workers engaged in foreign or interstate commerce."

The above quoted section is the most unsatisfactory part of the statute. In particular, there is evident confusion in defining admiralty matters as to which arbitration is made compulsory. A much happier result would have been reached if the first part had read "that maritime transactions include all matters which if the subject of controversy would be embraced within admiralty jurisdiction," instead of as the section now reads. As it is, certain classes of disputes of acknowledged admiralty jurisdiction are included, whereas others are apparently excluded; the draftsman was also apparently under the erroneous impression that admiralty jurisdiction did not exist unless foreign commerce was involved. ${ }^{7}$

An illustration will give point to the deficiencies of the section as it now reads. Let us suppose that salvage services are rendered an American vessel off the coast of the United States. The amount of a salvage award is easily susceptible of arbitration; and yet it would seem that such an agreement might not fall within the statute unless under the circumstances the rendering of the service amounted to "foreign commerce." Let us suppose again that a tug is hired to tow a barge from New York to Brooklyn, or within the limits of Boston harbor. There is every reason why the Arbitration Act should apply to such a contract and yet, apparently through oversight, it has been excluded. The statute also omits all reference to marine insurance, a subject matter of acknowledged admiralty jurisdiction.

It might be said that such agreements as do not fall within the Act will be taken care of by like acts which will presumably be passed by the various states. As will be pointed out later, however, the decisions leave this question of conflict between the state and the federal acts in a very unsatisfactory condition; there will probably be a number of controversies which are not covered by either and it will no doubt often be difficult to determine in which category the controversy falls.

The procedure which is outlined in the Act seems admirably

${ }^{7}$ See Ex parte Boyer, 109 U. S. 629, 3 Sup. Ct. 434 (1884). 
to achieve the result intended. ${ }^{s}$ Especially to be mentioned is the provision ${ }^{3}$ that in an admiralty suit when property has been attached, the arbitration may continue during the pendency of the suit and the court's decree shall be entered upon the award. The obvious purpose of this section is to cover cases where one party is a foreigner. If he were free to take his property from the jurisdiction pending the arbitration, the rendering of an award might, in a number of cases, be entirely fruitless. Some such provision was obviously necessary to insure that payment would be made.

It should be noted also ${ }^{10}$ that, generally speaking, the award can be upset only in cases of misconduct on the part of the arbitrators, which misconduct may be altogether innocent. Proof of corruption or fraud obviously will result in upsetting the award. The award may also be vacated where the arbitrators refuse to postpone the hearing upon sufficient cause shown or refuse to hear "evidence pertinent and material to the controversy"; or are guilty of "any other misbehavior by which the rights of any party have been prejudiced." An imperfect award may also be set aside and, if the time within which the award must be made has not elapsed, the court has discretion to direct a rehearing.

In New York, where there is a similar statute, it has been held that where an arbitrator made an independent investigation of the facts without consultation of the parties, this was misconduct justifying the setting aside of the award.12

It has been thought by some people that once an arbitration statute is passed, all technicalities would be done away with and every controversy would be promptly decided on its merits. Unfortunately this is not the case. Disputes, which would be bitterly contested in court, will in all probability be likewise contested in arbitration proceedings. If a party believes that he can

8 Section 2 provides in substance that a written arbitration agreement within the scope of the Act shall be "valid, irrevocable and enforceable, save upon such grounds as exist at law or in equity for the revocation of any contract."

Section 3 gives the court the right to stay an action brought in violation of an arbitration agreement.

Section 4 covers the specific enforcement of an arbitration agreement and section 5 provides for the appointment of the arbitrators. In appointing an arbitrator or arbitrators the court must follow the method preseribed in the agreement to arbitrate; if no method is prescribed, then the court may designate any arbitrator it may wish.

Sections 6 and 7 are purely procedural covering the summoning of witnesses and applications to the court, which are to be heard as motions.

Section 8.

10 Sections 9,10 and 11 deal with the confirmation, upsetting or modification of the award.

11 Berizzi Co. v. Krausz, 239 N. Y. 315, 146 N. E. 436 (1925). 
obtain an advantage by a technicality, he will avail himself of it irrespective of the tribunal. This is shown by the records of the courts which contain many instances of litigation under arbitration agreements having little or nothing to do with the merits.

Experience with the New York Act shows the classes of questions which are likely to arise and in view of the similarity of the two acts, it would seem that decisions under the New York Act were authoritative in the construction of the federal statute. In the first place, the United States Act provides that agreements to arbitrate shall be valid, irrevocable and enforceable. Suppose that one party to such an agreement brings suit against the other, who files an answer without relying upon the arbitration clause. May either party later, without the consent of the other, insist on arbitration? After some fluctuation of opinion, the New York courts have come to the conclusion that a party who wishes to avail himself of arbitration must do so promptly. If his conduct indicates a preference for litigation, he cannot later change his mind..$^{22}$ The result reached is obviously based on common sense and it is to be expected that the federal statute will be interpreted in the same way.

Secondly, suppose that the arbitration agreement provides for an arbitration outside of the United States, as is very common in maritime transactions. It is quite clear that a United States court could hardly specifically enforce such an agreement, as the machinery provided in the Act contemplates the control of the arbitration by the United States District Court. ${ }^{13}$ On the other hand, the court might conceivably stay the suit under the provision of section 3 until arbitration was had in the foreign jurisdiction. It is, however, doubtful if a court could, or should, grant a stay to await the termination of an arbitration over which it would have little or no control. Almost every section of the Act seems to contemplate an arbitration taking place in the United States and it would seem going very far to say that a stay should be granted under section 3, although the agreement provided for arbitration elsewhere. On the other hand, it has been held in New York, though not by a court of last resort, that a stay will be granted although the arbitration is to take place in a foreign jurisdiction. ${ }^{14}$

Thirdly, the question has arisen as to the course to pursue where one party wishes to arbitrate and the other refuses. Section 4 of the Act provides "That a party aggrieved by the alleged failure, neglect, or refusal of another to arbitrate under

12 Matter of Zimmerman \& Cohen, 236 N. Y. 15, 139 N. E. 764 (1923).

13 See $\$ 7$.

14 Matter of Inter-Ocean Food Products, Inc., 206 App. Div. 426, 201 N. Y. Supp. 536 (1st Dept. 1923). 
a written agreement for arbitration may petition any court of the United States which, save for such agreement, would have jurisdiction . . . for an order directing that such arbitration proceed in the manner provided for in such agreement" [our italics]. If we suppose that the arbitration agreement is drawn so as to be self-executing, $i$. e., so that it is unnecessary to compel the other party to take any action in order to have the arbitration proceed, must resort still be had to the courts?

Curiously enough, this situation has come before the House of Lords under section 3 of the New York Act, which is practically identical with the Federal Act.15 The action was to enforce an award made in New York under an agreement between two insurance companies. After disputes had arisen, the American company proposed arbitration, but the English company refused to take any part therein. The American company thereupon appointed both arbitrators, as it was entitled to do by the terms of the contract. After the award had been made, it was disputed by the English company on a number of grounds, among which was that the American company should have applied to the Nev: York courts in accordance with section 3.

The difficulty of the question is emphasized by the divergent opinions of the judges, the Court of Appeal reversing the lower court and being, in turn, reversed by the House of Lords. During the pendency of the action, there happened to take place a meeting of the American Bar Association in London. This opportunity was availed of to obtain the opinions of many prominent American lawyers as to the meaning of the New York statute. Their opinions, which were made a part of the case, were also widely divergent. In the House of Lords the decision of the New York Court of Appeals in Bullard v. Grace Co ${ }^{16}$ which had been handed down after the decision in the lower courts, was relied upon as showing that an application to the court vias necessary. Consequently, the arbitration proceedings were set aside. This case, together with many others, illustrates the fact that the passage of the Arbitration Act has by no means done away with technicalities.

Conflicts between the federal and state laws will undoubtedly arise in the future. If interstate commerce is involved, then of course arbitration must take place in accordance with the Federal Act. So if the subject matter is within the admiralty jurisdiction, relief in accordance with the United States Act must be sought. Difficulty will often arise in solving this question of jurisdiction. Very many contracts are on the border line between intra- and inter-state transactions. In the same way,

${ }^{15}$ Bankers \& Shippers Ins. Co. of N. Y. v. Liverpool MIarine Ins. Co., 21 Lloyds List L. Rep. 85 (H. L. 1925).

${ }^{16} 240$ N. Y. 388, 148 N. E. 559 (1925). 
it is also often difficult to be sure whether a contract is within the jurisdiction of the admiralty courts. In the absence of an arbitration clause, suit in cases of doubt can always be brought at common law since the common law jurisdiction is substantially all-embracing. When, however, arbitration is sought, it will be necessary to be certain which court has jurisdiction. An erroneous choice at the outset might result in having all of the proceedings subsequently set aside.

The decisions prior to the Federal Statute are perhaps of some help in solving these questions of jurisdiction. In any event, it would seem worth while to refer to the remarkable litigation arising out of one of the voyages of the steamship Runa.

The Runa, a small Scandinavian steamer, was time-chartered by her owners to the Atlantic Fruit Company, which company, in turn, sub-chartered her to the Red Cross Line. During one of her voyages she met with stormy weather with the result that she deviated from her course, causing serious loss to the Red Cross Line. The Red Cross Line presented its claim to the Atlantic Fruit Company, which rejected it. The Red Cross Line then demanded arbitration in New York in accordance with one of the clauses of the charter party. The Atlantic Fruit Company refused to arbitrate, suggesting that the Red Cross line should bring suit against it in admiralty, which would afford the Atlantic Fruit Company the opportunity of impleading, in accordance with the admiralty practice, the steamer and her owners, so that if an obligation were found to exist, it could be passed on to the party which ought to bear it. However, for reasons which seemed good to it, the Red Cross line insisted on arbitration, and brought suit in a New York state court under the New York Arbitration Law to compel arbitration. The Atlantic Fruit Company resisted on the ground that the charter party was a maritime contract and that the remedy given in judicial proceedings was exclusive. This contention of the Atlantic Fruit Company was upheld by the New York Court of Appeals. ${ }^{27}$

However, the case was taken further with the result that the Supreme Court reversed the Court of Appeals, holding ${ }^{18}$ that despite the admiralty nature of the controversy, a remedy might be obtained under the New York Arbitration Law. The conclusion of the Supreme Court is based on the following grounds: ${ }^{10}$

"By reason of the saving clause, state courts have jurisdiction in personam, concurrent with the admiralty courts, of all causes

17 Matter of Red Cross Line v. Atlantic Fruit Co., 233 N. Y. 373, 135 N. E. 821 (1922).

18 Red Cross Line v. Atlantic Fruit Co., 264 U. S. 109, 44 Sup. Ct. 274 (1924).

19 At 123, 44 Sup. Ct. at 277. 
of action maritime in their nature arising under charter parties. Judiciary Act of September, 24, 1789, c. 20, § 9, 1 Stat. 73, 77; Judicial Code, \$ 24, par. 3; Lcon $\%$ Galccran, 11 Wall. 185; Schoonmaker v. Gilinore, 102 U. S. 118; Chappell r. Eiadshaw, 128 U.S. 132; De Lovio v. Boit, 2 Gall, 398, 475. The 'right of a common law remedy', so saved to suitors, does not, as has been held in cases which presently will be mentioned, include attempted changes by the States in the substantive admiralty law, but it does include all means other than proceedings in adriniralty which may be employed to enforce the right or to redress the injury involved. It includes remedies in pais, as well as proceedings in court; judicial remedies conferred by statute, as well as those existing at the common law; remedies in equity, as well as those enforceable in a court of law. Innapp, Stout \& Co. 2. MCCaffrey, 177 U. S. 638, 644, et seq.; Rounds v. Cloucipoit Foundry \& Machine Co., 237 U. S. 303. A State may not provide a remedy in rem for any cause of action within the admiralty jurisdiction. The Hine v. Tievor, 4 Wall. 555; The Glide, 167 U.S. 606 . But otherwise, the State, having concurrent jurisdiction, is iree to adopt such remedies, and to attach to them such incidents, as it sees fit. New York, therefore, had the power to confer upon its courts the authority to compel parties within its jurisdiction to specifically perform an agreement for arbitration, which is valid by the general maritime law, as well as by the law of the State, which is contained in a contract made in New York and which, by its terms, is to be performed there."

Concluding its opinion, the Supreme Court said: ${ }^{\circ 0}$

"As the constitutionality of the remedy provided by New York for use in its own courts is not dependent upon the practice or procedure which may prevail in admiralty, we have no occasion to consider whether the unwillingness of the federal courts to give full effect to executory agreements for arbitration can be justified."

This decision settled that a party to a contract containing an arbitration clause could obtain specific performance through the state courts even though the contract was one of a maritime nature. The question, however, still remained open as to whether, if one of the parties to such a contract preferred to bring his suit in the federal court, the federal court would allow the arbitration clause as a defense. This question is answered in Atlantic Fruit Company v. Red Cross Line,21 a suit to recover charter hire during the period of the alleged deviation of the Runa. At the trial the Red Cross line failed to make good the defense which it had set up as to the misconduct of the MIIster, and the question principally considered on the appeal was as to the effect of the New York statute as a bar to the suit.

In holding that the New York statute was not a bar, Judge Hough said: ${ }^{22}$

20 At 125, 44 Sup. Ct. at 278.

215 Fed. (2d) 218 (C. C. A. 2d, 1924).

22 At 219-220. 
"The arbitration statute of New York changed the common law, or at least the common-law method of thinking about arbitration in that state. What New York and other courts regarded as the 'common-law limitation upon enforcement of promises to arbitrate' was a part of the law of remedies, which is always a portion of the law of the forum. Therefore the statute itself relates altogether to remedies.

"Since The Lottawanna, 21 Wall. 558, 22 L. Ed. 654, it seems superfluous to further discuss the proposition that the states acting through their Legislature or their courts cannot create a new remedy enforceable in the admiralty, nor take away any remedy there already existing. There are instances in which new substantive legal rights created by the states may be enforced by remedies of its own in the admiralty, but it is entirely plain that this matter of arbitration, whether based on a New York statute or resting upon traditional and judge-made law, is wholly matter of remedy.

"We therefore hold that the Arbitration Act of New York, although affording a remedy in respect of this charter party, has no effect upon whatever remedy the admiralty offered for the settlement of disputes arising under the same charter party."

Prior to the federal statute, therefore, the remarkable result was reached that arbitration of an admiralty controversy could be specifically enforced in proceedings in the state court, but that, at the same time, federal courts, sitting in admiralty, would not admit the arbitration statutes as a defense. The decision of the Circuit Court of Appeals was rendered after that of the Supreme Court, and consequently must be accepted as the law today.

While this controversy relating to the Runa has been made largely academic because of the federal statute, there are still certain disputes of admiralty cognizance which it would seem are not covered by the Federal Act; to these the decisions just noted would apply.

Another controversial element in the federal statute is the limited number of grounds on which the decision of the arbitrator may be reviewed. In general, it may be said that two schools of thought exist as to arbitration. One school is in favor of allowing quite a full review of the result. The other school, which has found favor in New York and with Congress, considers that an arbitration award should stand unless fraud or misconduct can be shown. In other words, once the parties have agreed upon arbitration, they must accept the result the arbitrator reaches no matter how obviously and plainly wrong it appears.

The English Act provides rather elaborately for a judicial review of the arbitrator's decision, and it will be worth while to consider briefly the practice under the English Act in order to compare it with the American. Under the English statute ques- 
tions of law arising in the arbitration may come before the courts in two ways. ${ }^{23}$

By section 19: "Any referee, arbitrator, or umpire may at any stage of the proceedings under a reference, and shall, if so directed by the Court or a judge, state in the form of a special case for the opinion of the Courts any question of law arising in the course of the reference."

If an arbitrator or umpire states a case under this section, the case is referred to a Divisional Court which renders what is termed a consultative opinion, from which no appeal can be taken. ${ }^{24}$

Section 7 provides: "The arbitrators or umpire acting under a submission shall, unless the submission expresses a contrary contention, have power . . . (b) to state an award as to the whole or part thereof in the form of a special case for the opinion of the Court."

Under this section the arbitrators or umpire have absolute discretion as to whether or not at the termination of their labor's they will state a case for the opinion of the court. Such a case, when stated, comes first before the King's Bench Division and an appeal may be taken in ordinary course to the Court of Appeal and ultimately to the House of Lords. This latter method of bringing commercial questions before the highest judicial body in the United Kingdom is frequently availed of. In passing on a case stated, the judges refuse to review the facts but are free to differ with the legal conclusions drawn therefrom by the arbitrator. It is held to be contrary to public policy for the parties by their contract to agree to waive a resort to the courts under the English Arbitration Act. ${ }^{25}$

This is, of course, not the place to discuss the many nice questions raised in the English cases, such as that the repudiation of the substance of a contract disentitles the party so repudiating to claim arbitration, ${ }^{20}$ or that if a contract is "frustrated," the arbitration clause goes with it, ${ }^{27}$ or that unseawrorthiness may prevent a shipowner claiming arbitration."3

It has been customary in this country to follow rather closely the English practice, and an effort may subsequently be made to alter our Federal Act so as to allow a judicial review of the arbitrators' conclusions of law. The question will then be pre-

${ }^{23}$ See Mitrovitch Bros. \& Co. v. Hickson, Ltd., 14 Lloyds List L. Rep. 164 (K. B. 1923).

24 Larrinaga \& Co. v. Société Franco-Americaine, 27 Com. Cas. 160, 161 (1922) ; Cogstad \& Co. v. Newsum Sons \& Co. [1921] 2 A. C. 528.

${ }^{25}$ Czarnikow v. Roth Schmidt \& Co. [1922] 2 K. B. 478.

${ }^{26}$ Jureidini v. Nat'l British Ins. Co. [1915] A. C. 499; The Atlanten, 252 U. S. 313, 40 Sup. Ct. 332 (1920).

${ }^{27}$ Hirji MIulji v. Cheong S. S. Co., 42 T. L. R. 359 (P. C. 1926).

28 Ford \& Co. v. Furness \& Co. [1922] 2 K. B. 797. 
sented as to whether it is not better to require the parties to select arbitrators qualified to decide all of the points in controversy, so that the result reached will, in the absence of misconduct, be final, or whether a suit at law ought in almost all cases to be superadded to the arbitration proceedings. It is submitted that the American method of procedure is, in the vast majority of cases, preferable since the reservation of a right to review by the courts adds considerably to the potential expense of the proceedings and is, in substance, adding a fifth wheel to the wagon. If the parties are not prepared to abide by the results reached by the arbiters chosen by themselves, it would seem that they should bring their disputes into court directly. of couse there may be cases where large sums are at stake and it is felt that there should be an opportunity to review the arbitrators' decision and to correct any mistakes, inadvertent or otherwise. In such comparatively rare cases, the arbitration agreement could well be drawn to provide for a review by a board of appeal.

The arbitration statutes are now with us, and it is exceedingly unlikely that they will ever be repealed. They must, therefore, be studied by lawyers, for clients will wish advice, not only as to the technical questions involved, but also in general as to the advisability of arbitration as compared with proceedings in court. A few moments reflection will, it is believed, convince anyone that in many cases the client should be advised to litigate rather than to arbitrate. Every case must be considered by itself; a general rule cannot be laid down. Of course if a jury trial must be had and if it is certain that no matter what the result an appeal, or possibly two appeals, will be taken, with the possibility of reversals and new trials extending almost ad infinitum, then arbitration is much preferable, since the cost of litigation of that character very soon exceeds the amount in dispute. On the other hand, where the facts will be dealt with by a trial court and where one appeal will finally dispose of the case, there are strong arguments against arbitrating.

The procedure in our admiralty courts may be taken as an example of litigation in its most favorable aspect. An admiralty case is tried by one of the United States district judges, who decides both questions of fact and questions of law. If the amount of damages is liquidated or undisputed, a decree is entered directly on his opinion. If the amount of damages is disputed, that question is referred to a commissioner, a lawyer appointed by the court, which may be compared with the practice of appointing arbitrators under the Arbitration Act. In case the appointment of a commissioner is necessary, a final decree is entered upon his report, after confirmation. 
An appeal may be taken from the decision of the District Court to the Circuit Court of Appeals. The Circuit Court of Appeals reviews both facts and law, giving great weight to the conclusion of the District Court, however, as to the facts in cases where the witnesses have testified in open court. The decision of the Circuit Court of Appeals in all but an insignifcant number of cases finally disposes of the controversy one way or the other. There is a theoretical right of review by petition for writ of certiorari to the Supreme Court of the United States, but such a writ is very rarely granted, and then only in cases of great moment where large amounts are involved. The Circuit Court of Appeals also occasionally requires a further assessment of the damages, if it considers that these have been determined below on a wrong theory.

The only considerable item of expense is that of printing the record and testimony for the Circuit Court of Appeals. Against that must be balanced the fact that the parties do not have to pay anything to the court, whereas in an arbitration the fees of the arbitrators often amount to considerable sums.

Limiting the discussion to disputes relating to maritime matters, it will be seen that the only advantages of arbitration over litigation are (1) that while the present crowded condition of our court calendars continues, a result can probably be reached more quickly in arbitration proceedings and (Q) that where a case involves questions requiring technical knowledge, it may be to the advantage of the parties to have them determined by an expert rather than by a judge who has had no opportunity to study the subject. In view of the fact that the parties are not put to any expense in securing the services of a judge, it is doubtful if, so far as cheapness is concerned, there is any decided advantage in favor of arbitration; in fact, when all of the expenses are taken into consideration, it will be found that many cases can be more economically disposed of by litigation than by arbitration. While there is a prevailing impression that arbitration is the cheaper, this is due to the fact that, when arbitration was not compulsory, disputes settled in this way were only those of comparatively little importance where the parties were on friendly terms. Where an arbitration under the statute involves a mass of detail and where a bitter spirit develops, the cost will undoubtedly accumulate just as it would in a lawsuit involving the same subject matter; with the further disadvantage that the arbitrators will undoubtedly be more liberal in admitting evidence and in granting delays than will a court.

The principle of arbitration is, in substance, no more than allowing the parties to select and pay their own arbiter rather than to have one thrust upon them by the government. While 
the passage of the Federal Act is beneficial, if it does no more than to compel the full observance of agreements deliberately entered into, it can by no means be relied upon as a solution of all litigious matters. If due consideration is given before an arbitration agreement is entered into, if the arbitrator is carefully chosen, if the procedure under the Act is carefully studied, and if the parties are sincere in their desire to have the controversy determined on its merits, then a statutory arbitration will be a success. 